DOI: $10.21802 / \mathrm{artm} .2019 .2 .10 .57$.

УДК 616.151.514-085-071

\title{
РОЛЬ ТРОМБОЕЛАСТОГРАФІЇ У КОНТРОЛІ ПРОФІЛАКТИЧНОГО ЛІКУВАННЯ ХВОРИХ НА ТЯЖКУ ФОРМУ ГЕМОФІЛІЇ А БЕЗ ІНГІБІТОРІВ
}

\author{
В.В. Красівська ${ }^{1}$ О.В. Стасишин ${ }^{2}$, М.М. Семерак ${ }^{2}$, О.М. Тушницький ${ }^{3}$ \\ ДУ «Інститут патології крові та трансфузійної медицини НАМН Украӥни», \\ ${ }^{1}$ Лабораторія імунології та генетики неоплазій крові, \\ ${ }^{2}$ Відділення загальної та гематологічної хірургї̈, \\ ${ }^{3}$ Центр трансплантаиії стовбурових та гемопоетичних клітин, м. Львів, Украӥна, \\ ORCID ID: 0000-0002-7048-0711, ORCID ID: 0000-0002-8366-5926, \\ ORCID ID: 0000-0001-7394-2590, ORCID ID: 0000-0003-2106-5623, \\ e-mail:ipktm@ukr.net
}

Резюме. Мета. На основі вивчення показників ТЕГ та традиційних тестів дослідження гемостазу удосконалити лабораторний моніторинг профілактичного лікування препаратами концентратів факторів у хворих на гемофілію А.

Матеріали і методи. Дослідження виконано у 9 хворих на тяжку форму гемофілії А без інгібіторів, профілактична доза лікування яких становила $45 \pm 5$ МO/кг фактора зсідання VIII (ФVIII) 2 рази на тиждень. Визначення проводили на плановому візиті у тесті відновлення (ТВ) (доза $60 \pm 5 \mathrm{MO} /$ кг). Аналізували показники ТЕГ у комплексі із показниками гемостазу, активністю ФVIII, антигеном ФVIII (ФVIII:Ag), антигеном фактора Віллебранда (vWF:Ag).

Результати. До введення препарату ФVIII тести, які обумовлюють коагуляційний гемостаз, є достовірно подовженими порівняно із здоровими особами. У ТВ до введення препарату показники ТЕГ, які залежать від рівня прокоагулянтів, є порушеними у бік гіпокоагуляції. Через 30 хв після введення АЧТЧ, І АЧТЧ, активність ФVIII та ФVIII:Ag, R, TMA, $\alpha$-Angel, CI, SP нормалізуються.

Висновки. ТЕГ є надійним методом контролю профілактичного лікування та ТВ у хворих на тяжку форму гемофілії А. Аналізу підлягають показники, значення яких залежить від рівня прокоагулянтів: час реакції R, час досягнення максимальної амплітуди TMA, кут нахилу до дотичної ТЕГ $\alpha$-Angel, загальний коагуляційний потенціал CI, час від початку тесту до утворення перших ниток фібрину SP. Показники ТЕГ, які характеризують силу, якість, гемостатичні можливості, лізис згустку та залежать від вмісту фібриногену і тромбоцитів, не відрізняються від відповідних показників здорових осіб та є неінформативними для контролю замісної трансфузійної терапії та ТВ у хворих на гемофілію. У хворих на гемофілію моніторинг профілактичного лікування та появи інгібіторів до ФVIII може здійснюватись на основі ТВ за допомогою ТЕГ у комплексі із іншими тестами дослідження гемостазу: АЧТЧ, I АЧТЧ, активність ФVIII та ФVIII: Ag.

Ключові слова: гемофілія, профілактика, тромбоеластографія.

Вступ. Гемофілія - це спадкове порушення процесу зсідання крові, яке обумовлене зниженням або порушенням синтезу факторів згортання крові VIII (ФVIII) або IX (ФIX). У хворих на гемофілію в основі досягнення гемостазу під час лікування гострих геморагічних епізодів лежить підняття дефіцитного фактора до ефективного рівня. Значне місце в сучасному лікуванні цих пацієнтів займає профілактична короткотермінова та довготривала замісна трансфузійна терапія концентратами факторів згортання крові, яка проводиться 3 метою попередження спонтанних кровотеч та розвитку гемофілічних артропатій [1].

Обгрунтування дослідження. У хворих на тяжку форму гемофілії зустрічаються відмінні клінічні фенотипи кровотеч, тому вони потребують не однакових режимів введення препаратів у різних дозуваннях. В зв'язку із високою вартістю препаратів факторів згортання їх використання має бути оптимізованим та раціональним, тому вивчення фармакокінетики є підгрунтям у виборі дози препарату та часто- ти введення. Крім того, у 10-25\% хворих на гемофілію під час лікування з'являються інгібіторні антитіла до ФVIII (IX), які призводять до розвитку резистентності до замісної терапії [2]. Тест відновлення (ТВ) належить до фармакокінетичних параметрів, які застосовуються для характеристики поведінки ФVIII або ФIX в організмі. Також фармакокінетичні показники залежать від наявності інгібіторів, при виникненні яких знижується відновлення введеного фактора i/або прискорюється його кліренс [3]. Тому у хворих на гемофілію ТВ використовують як один із методів діагностики нейтралізуючих інгібіторних антитіл до ФVIII (IX). Вивчення фармакокінетичних параметрів, зокрема (ТВ), дозволяє індивідуалізувати лікування, виявити ранні ознаки резистентності, запідозрити інгібітор та уникнути розвитку небезпечних для життя кровотеч.

Останнім часом для контролю терапії хворих на гемофілію застосовують лабораторні методи, які засновані на комплексній оцінці гемостазу. До глобальних тестів відносять тромбоеластографію (ТЕГ) та 
тест генерації тромбіну (ТГТ) [4-7]. На відміну від традиційних методів, візкозиметричний метод ТЕГ висвітлює динаміку коагуляції у часі, iii параметри забезпечують більш детальну інформацію про процес зсідання і можуть відображати як гіпо- так і гіперкоагуляцію. ТЕГ забезпечує глобальну оцінку системи зсідання від ініціації утворення і розвитку згустку до фібринолізу в природних умовах, що включає взаємодію клітинних і плазматичних компонентів [8-10]. При моніторингу терапії за допомогою активованого часткового тромбопластинового часу (АЧТЧ) та активності ФVIII причиною невідповідності може бути неврахований вміст тканинного фактора, кількість та агрегативна функція тромбоцитів, які теж беруть участь в процесі коагуляції. Вважають, методи комплексної оцінки системи зсідання більш точно, на клітинному рівні відображають фізіологічні процеси та механізми впливу на гемостаз терапевтичних препаратів [8-10]. Однак, ТЕГ не є заміною для звичайних коагуляційних тестів, а лише доповнює їх результати. Тому при оцінці кровоточивості, дані ТЕГ слід інтерпретувати з обережністю, беручи до уваги клінічні прояви та результати інших лабораторних досліджень [8]. Отже, вивчення інформативності ТЕГ для оцінки гемостатичної дії та контролю лікування концентратами факторів зсідання хворих на гемофілію $є$ актуальним завданням.

Мета. На основі вивчення показників ТЕГ та традиційних тестів дослідження гемостазу удосконалити лабораторний моніторинг профілактичного лікування препаратами концентратів факторів у хворих на гемофілію А.

Матеріали і методи. Дослідження виконано у 9 хворих (10 спостережень) на тяжку форму гемофілії А (ФVIII $<1,0 \%$ ) віком від 1,5 до 60 років), які протягом 2017 року знаходилися на профілактичному лікуванні у ДУ «Інститут патології крові та трансфузійної медицини НАМН України». Профілактична доза становила $45 \pm 5 \mathrm{MO} /$ кг препарату пролонгованого рекомбінантного фактора VIII 2 рази на тиждень. Згідно з міжнародними рекомендаціями [2] на плановому візиті всім хворим, які не мали активних крововиливів, проводили ТВ введеного фактора в дозі $60 \pm 5$ $\mathrm{MO} / к г$ препарату. Всім пацієнтам до та 30 хв після закінчення введення розрахованої дози препарату ФVIII було виконано коагулологічні дослідження та TEГ.

Підготовка плазми для дослідження. У пластиковій пробірці кров стабілізували $3,2 \%$ розчином цитрату натрію у співвідношенні 1 частина стабілізатора до 9 частин крові. Для виконання тромбоеластограми використовували нативну цитратну плазму. Для коагулологічних досліджень кров послідовно центрифугували в двох режимах (7 хв при $110 \mathrm{~g}$ та 20 хв при $2000 \mathrm{~g}$ ) до отримання збідненої на тромбоцити плазми.

Для загальної оцінки стану системи гемостазу виконували скринінгові дослідження: протромбіновий час (ПЧ) з розрахунком протромбінового індексу (ПІ), АЧТЧ, визначення концентрації фібриногену гравіметричним методом [11]. Для коректного співставлення результатів розраховували індекс АЧТЧ (І відношення часу зсідання хворого до часу зсідання нормальної плазми. До та після введення препарату за уніфікованою одностадійною методикою визначали активність ФVIII [11]. Всім хворим проводили обстеження на наявність інгібіторних антитіл до ФVIII методом Bethesda-Nijmegen [12] У обстежених пацієнтів інгібіторних антитіл не виявлено. Антиген ФVIII (ФVIII:Ag) та антиген фактора Віллебранда (vWF:Ag) визначали імунферментним методом. Кількість тромбоцитів була підрахована апаратним методом за стандартною методикою.

ТЕГ виконували на тромбоеластографі TEG $5000^{\circledR}$ Haemoscope Corp., Niles IL. У кювету тромбоеластографа додавали 340 мкл цитратної крові та 20 мкл $0,2 \mathrm{M}$ розчину $\mathrm{CaCl}_{2}$. Було проаналізовано такі показники системи зсідання: час реакції $(\mathrm{R}, \mathrm{xв})$; час коагуляції або формування згустку (К, хв); кут дотичної до ТЕГ з точки початку утворення згустку $(\alpha-$ Angle, градуси); максимальну амплітуду (МА, мм); час максимальної амплітуди (ТМА, хв); коагуляційний індекс - потенціал крові пацієнта в цілому (CI); час початкового утворення фібрину (SP, хв); стабільність та міцність згустку (G, діни/ $\left.\mathrm{cm}^{2}\right)$; LY30характеристика процесу розчинення згустку за 30 хв після досягнення МА або ступінь фібринолізу через 30 хв після утворення згустку; тромбодинамічний потенціальний індекс (TPI/c) [8-10]. Значення R та K зафіксовані протягом 10 хв після ініціації процесу зсідання у кюветі тромбоеластографа, $\alpha$-Angle, MA, G та LY30 - протягом 30 хвилин.

Контрольну групу для визначення нормальних коагулологічних показників склали 20 здорових осіб (10 чоловіків і 10 жінок середнього віку), які не приймали жодних ліків. Нормальні контрольні діапазони значень (референтний інтервал) показників тромбоеластограми для цитратних нативних зразків крові взято з літературних даних та надані виробником [8$10]$.

Статистичну обробку матеріалу виконали за допомогою пакетів прикладних програм STATISTICA for Windows 6,0 (Statsoft, USA). Порівняння параметричних показників між групами здійснювали за допомогою критерію Манн-Уітні та подавали їх як медіану, мінімум, максимум, нижній-верхній квартилі. Вірогідність отриманих результатів оцінювали на рівні достовірності не менше $95 \%(\mathrm{p}<0,05)$.

Результати дослідження та їх обговорення. Досліджуваних хворих на гемофілію було розділено на 2 групи. До I групи ми віднесли пацієнтів, які знаходились на профілактичному лікуванні, і яким проводили дослідження на плановому візиті. II групу склали ті самі 9 хворих (10 випадків) на гемофілію після введення концентрату препарату ФVIII у ТВ. Як видно з табл. 1, до введення препарату медіана ПЧ та ПІ становила $15,9(15,2-16,9)[15,6-16,6]$ с і 94,0(80,0$98,0)[88,5-97,0] \%$ відповідно, достовірної різниці 3 показниками здорових осіб не виявлено $\left(\mathrm{p}_{\mathrm{H}}=0,068\right.$; $\left.\mathrm{p}_{\mathrm{H}}=0,119\right)$. Після введення розрахованої дози препарату ПЧ та ПІ майже не змінились і залишались в межах норми 15,5(14,8-17,0)[15,3-16,1] с та 95,0(88,5100,0)[91,0-98,0]\% відповідно; у всіх випадках $\mathrm{p}_{\text {н }}>0,05$. Як видно 3 таблиці, значущої різниці між показниками ПЧ та ПІ у пацієнтів I та II групи не виявлено $\left(\mathrm{p}_{\mathrm{I}-\mathrm{II}}>0,05\right)$. У хворих на гемофілію А до 
введення препарату у ТВ показники тестів, які характеризують коагуляційний гемостаз, були значно порушені, порівняно із нормою, і становили 72,9(59,3101,2) $[69,0-89,0]$ с для АЧТЧ та 2,3(1,9-3,2)[2,2-2,8] для ІАЧТЧ; $\mathrm{p}_{\mathrm{H}}<0,0002$. За 30 хв. після введення (II група) АЧТЧ та ІАЧТЧ майже нормалізувались (медіана $37,2(32,3-46,6)[32,9-44,5]$ с та $1,2(1,0-1,5)[1,0-1,3]$ відповідно), але все ще залишались достовірно довшими за норму; $\mathrm{p}_{\mathrm{н}}=0,010$ та $\mathrm{p}_{\mathrm{H}}=0,008$. Також нами встановлено достовірну різницю значень АЧТЧ та ІАЧТЧ між I та II групами, медіана 72,9(59,3-
101,2)[69,0-89,0] с проти 37,2(32,3-46,6)[32,9-44,5] с та 2,3(1,9-3,2)[2,2-2,8] проти 1,2(1,0-1,5) [1,0-1,3]; p I${ }_{\mathrm{II}}<0,0001$. Значення фібриногену у I та II групах знаходились в межах норми. Між групами достовірної різниці вмісту фібриногену нами не встановлено, медіана була в межах 3,0 мг/мл (у всіх випадках $\mathrm{p}>0,05)$. До введення активність ФVIII була зниженою порівняно із нормою та хворими II групи, і становила $1,1(0,2-9,9)[0,3-2,7] \%\left(\mathrm{p}_{\mathrm{H}}<0,0001, \mathrm{p}_{\mathrm{I}-\mathrm{II}}<0,0001\right)$. У ТВ ФVIII нормалізувався до $119,0(92,1-175,7)[104,1-$ $142,6] \%$ (табл. 1).

Таблиця 1.

Показники системи зсідання та ТЕГ у хворих на гемофілію А у ТВ під час планового візиту

\begin{tabular}{|c|c|c|}
\hline Показник (норма), $n=20$ & I група, $n=10$ & II група, $n=10$ \\
\hline \multicolumn{3}{|c|}{ Показники системи зсідання } \\
\hline ПЧ, с $(14,0-16,0)$ & $15,9(15,2-16,9)[15,6-16,6]$ & $15,5(14,8-17,0)[15,3-16,1]$ \\
\hline$\Pi$ ПI, \% $(90,0-110,0)$ & $94,0(80,0-98,0)[88,5-97,0]$ & $95,0(88,5-100,0)[91,0-98,0]$ \\
\hline АЧТЧ, с $(25,0-35,0)$ & $72,9(59,3-101,2)[69,0-89,0] * \#$ & $37,2(32,3-46,6)[32,9-44,5] *$ \\
\hline І АЧТЧ $(0,8-1,2)$ & $2,3(1,9-3,2)[2,2-2,8] * \#$ & $1,2(1,0-1,5)[1,0-1,3] *$ \\
\hline Фібриноген, мг/мл $(2,0-4,0)$ & $3,0(2,5-3,5)[2,5-3,2]$ & $3,0(2,5-3,5)[2,5-3,5]$ \\
\hline Активність ФVIII, \% (50,0-150,0) & $1,1(0,2-9,9)[0,3-2,7] * \#$ & $119,0(92,1-175,7)[104,1-142,6]$ \\
\hline ФVIII:Ag, \% $(64,0-189,0)$ & $4,6(3,0-11,4)[3,6-6,4] * \#$ & $\begin{array}{l}126,5(106,7 \quad-213,8) \quad[116,5- \\
171,6]\end{array}$ \\
\hline vWF:Ag, \% $(50,0-160,0)$ & $115,1(76,0-183,0)[94,0-164,0]$ & - \\
\hline $\begin{array}{l}\text { К-ть тромбоцитів } \times 10^{9} / л(180,0- \\
320,0)\end{array}$ & $265,0(210,0-489,0)[240,0-274,0]$ & - \\
\hline \multicolumn{3}{|c|}{ Показники ТЕГ } \\
\hline $\mathrm{R}, \mathrm{xB}(4,0-11,0)$ & $21,9(16,5-44,4)[17,1-23,9]^{\#}$ & $10,4(2,3-16,6)[8,3-12,1]$ \\
\hline $\mathrm{K}$, хв $(1,0-4,0)$ & $5,8(1,6-8,2)[5,3-5,9]$ & $3,85(1,6-8,7)[3,7-5,0]$ \\
\hline MA, мм $(54,0-72,0)$ & $44,5(4,1-56,8)[43,2-50,1]$ & $50,0(40,0-65,0[46,0-55,8]$ \\
\hline TMA, $\mathrm{xB}$ & $46,5(30,6-63,2)[41,6-49,2]^{\#}$ & $30,5(22,6-49,6)[28,1-36,7]$ \\
\hline$\alpha$-Angel, град $(47,0-74,0)$ & $33,0(23,9-39,0)[29,6-36,1]^{\#}$ & $43,9(23,6-68,4)[38,4-48,6]$ \\
\hline $\mathrm{CI}(-3,0-+3,0)$ & $-3,0(-6,8-(-1,5))[-4,1-(-2,8)]^{\#}$ & $-0,2(-1,4-2,5)[-0,9-0,95]$ \\
\hline $\mathrm{SP}$, хв $(0,25-15)$ & $19,1(14,4-42,4)[15,3-21,7]^{\#}$ & $8,4(1,9-13,5)[6,9-10,7]$ \\
\hline $\mathrm{G}$, діни/см² $(6,0-13,2)$ & $4,0(0,2-6,6)[3,8-5,0]$ & $5,0(3,3-9,3)[4,3-6,3]$ \\
\hline LY30, \% $(0-8)$ & $0,0(0,0-33,8)[0,0-0,1]$ & $0,6(0,0-9,6)[0,2-4,4]$ \\
\hline TPI /c $(3,0-20,0)$ & $7,0(1,3-11,2)[5,2-8,5]$ & $10,8(4,2-58,6)[9,8-13,8]$ \\
\hline
\end{tabular}

\section{Примітки:}

1. Показники подано як «медіана (мінімум-максимум) [нижній- верхній квартилі]»,

2. *- Різниця з показником контрольної групи значуща $\left(\mathrm{p}_{\mathrm{н}}<0,05\right)$,

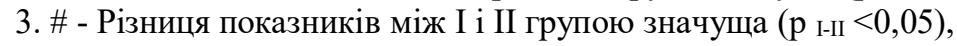

4. Пояснення скорочень показників системи зсідання та ТЕГ подано у матеріалах і методах.

Таку саму ситуацію ми спостерігали із зниженим порівняно із здоровими особами ФVIII: Ag (медіана 4,6(3,0-11,4) [3,6-6,4]\%; $\left.\mathrm{p}_{\mathrm{H}}<0,0001\right)$, який після введення препарату приходить до норми і становить 126,5(106,7-213,8) [116,5-171,6] \%. Показники vWF: Ag та кількості тромбоцитів у обстежених хворих до введення були в межах норми - медіана $115,1(76,0-183,0)[94,0-164,0] \%$ та $265,0(210,0-$ $489,0)[240,0-274,0] \times 10^{9} / л \quad$ відповідно $\quad\left(\mathrm{p}_{\mathrm{H}}=0,164\right.$ та
$\left.\mathrm{p}_{\mathrm{H}}=0,377\right)$. Після введення препарату їх вимірювання не проводили.

Результати ТЕГ у обстежених хворих на гемофілію у ТВ представлено у табл. 1 та на рис. 1, 2. У I групі показник часу реакції R був вищий за норму (медіана 21,9(16,5-44,4)[17,1-23,9] хв при нормі 4,011,0 хв), що характерно для цієї категорії пацієнтів із порушенням коагуляційної (ензиматичної) фази зсідання крові (рис.1, 2). 


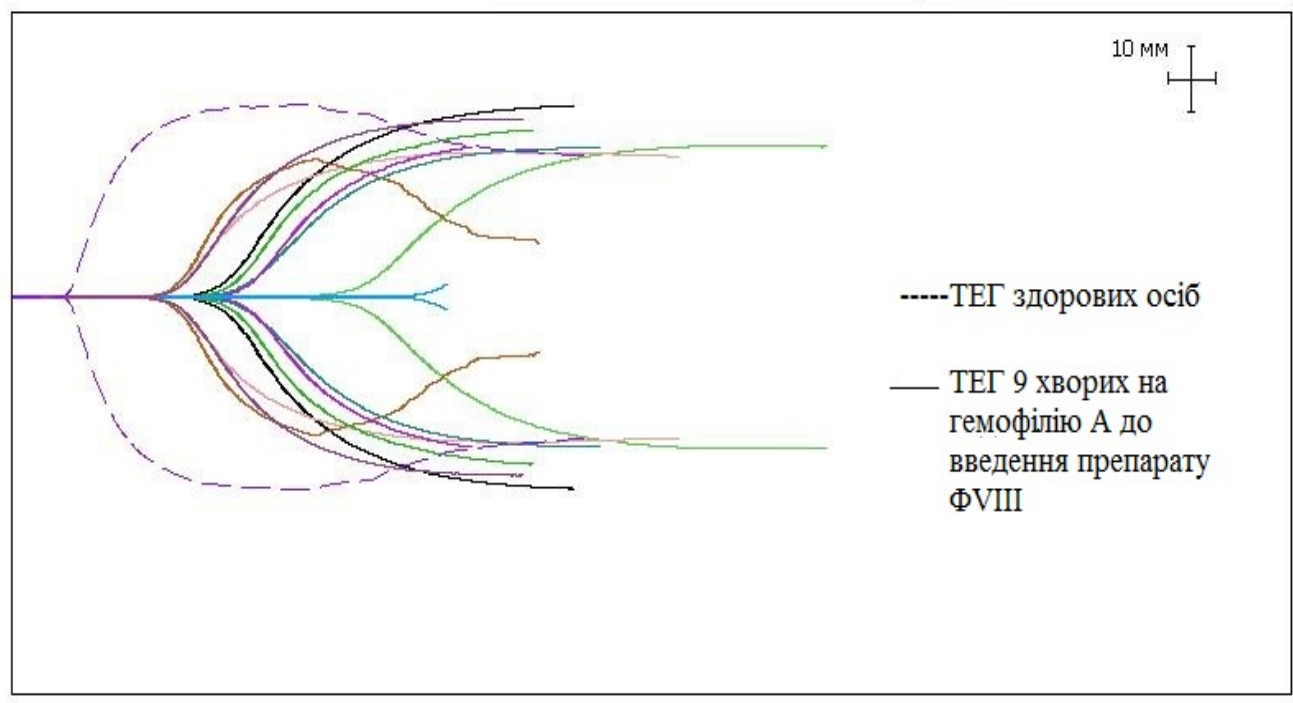

Рис. 1 - ТЕГ 9 хворих на гемофілію А у ТВ до введення концентрату препарату ФVIII

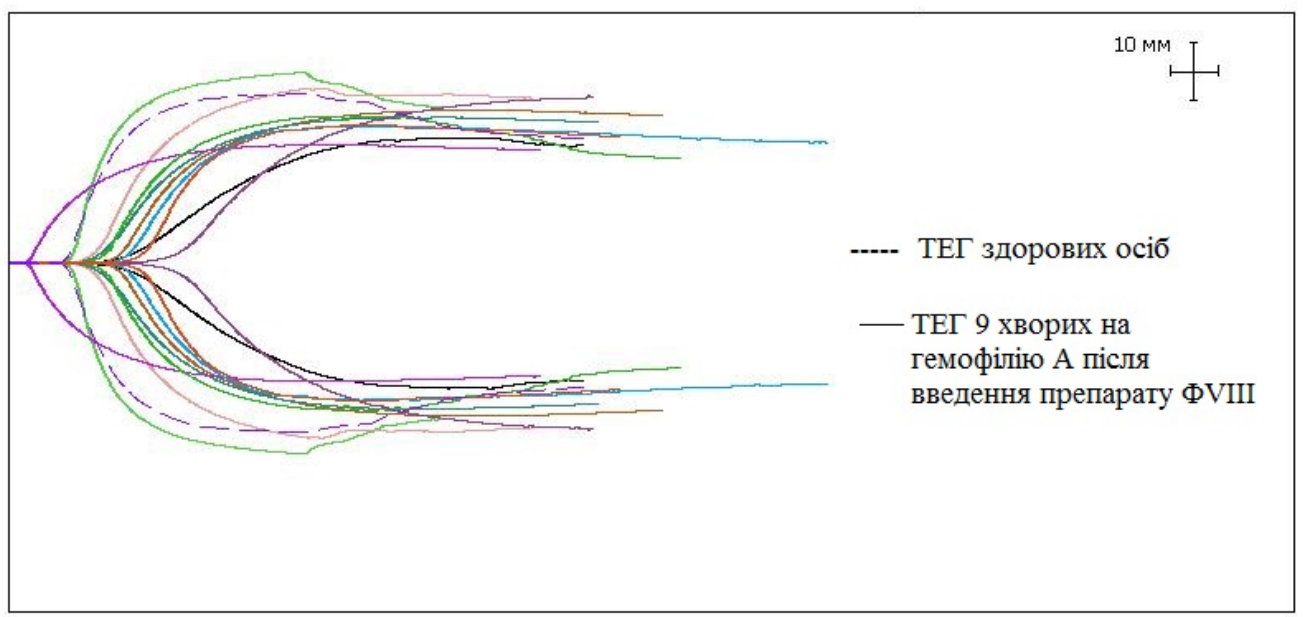

Рис. 2 - ТЕГ 9 хворих (10 випадків) на гемофілію А після введення концентрату препарату ФVIII

У хворих на гемофілію час до формування критичної маси тромбіну (фібрину) є значно подовженим, завдяки дефіциту прокоагулянта. Після введення розрахованої дози препарату ФVIII, час зсідання (утворення тромбопластину та тромбіну) нормалізується до 10,4 (2,3-16,6) [8,3-12,1] хв. (рис 2.). Також нами виявлено достовірну різницю між показниками R y I та II групах ( $\left.\mathrm{p}_{\text {I-II }}=0,001\right)$, що вказує на компенсацію дефіциту фактора зсідання у хворих на гемофілію А у ТВ. Показник К, який залежить від кінетики (швидкості) досягнення певного рівня сили згустку амплітуди 20 мм, у хворих обох груп майже не відрізняється від нормальних значень (у всіх випадках $\mathrm{p}>0,05)$. Максимальна амплітуда (МА), що характеризує щільність згустку та залежить від вмісту тромбоцитів та фібриногену, у хворих до та після введення препарату залишалась нормальною, між групами достовірної різниці не встановлено (табл. 1). У хворих II групи після введення концентрату препарату ФVIII показник ТМА значно вкоротився, порівняно із хворими до введення 30,5 (22,6-49,6) [28,1-36,7] хв проти 46,5(30,6-63,2) [41,6-49,2] хв ( $\left.\mathrm{p}_{\mathrm{I}-\mathrm{II}}=0,002\right)$. Кут $\alpha$-Angel, побудований по дотичній до ТЕГ з точки початку утворення згустку, у I групі був меншим за норму і становив 33,0 $(23,9-39,0)[29,6-36,1]^{\circ}$. Зниження нахилу (кута) між $\mathrm{R} \mathrm{i} \mathrm{K}<45^{\circ}$ вказує на гіпокоагуляцію та у хворих на гемофілію А пов'язане із дефіцитом ФVIII. У ТВ швидкість росту фібринової сітки приходить до норми та $\alpha$-Angel достовірно зростає до нормальних значень (медіана 43,9 $(23,6-68,4)$ $[38,4-48,6] ; p=0,026)$. Як видно з табл. 1 , на гіпокоагуляцію у пацієнтів I групи вказує від'ємне значення коагуляційного індексу (медіана СI -3,0(-6,8-(-1,5)) [$4,1-(-2,8)])$, який після введення препарату нормалізується і становить - 0,2 (-1,4-2,5) [-0,9-0,95] при нормі $(-3,0-+3,0) ; p=0,001$. Зниження глобального індексу та гемостатичного статусу у хворих на гемофілію обумовлене дефіцитом ФVIII, який після введення концентрату фактора у ТВ досягає норми.

До введення препарату із зниженим рівнем ФVIII пов'язане подовження показника SP, який відображає час від початку тесту до розколу кривої 
ТЕГ при утворенні перших ниток фібрину. При нормі 0,25-15 хв медіана SP у I групі становила $19,1(14,4-$ $42,4)[15,3-21,7]$ хв. Після введення препарату час SP зменшився до 8,4(1,9-13,5)[6,9-10,7] хв $\left(\mathrm{p}_{\mathrm{IIII}}=0,001\right)$. Аналізуючи загальну функцію та ефективність згустку у хворих I та II групи, ми спостерігаємо деяке

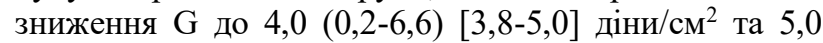
(3,3-9,3)[4,3-6,3] діни/см², відповідно, без достовірної різниці між показниками до та після введення концентрату препарату ФVIII (табл. 1). Показник літичного індексу LY30, який залежить від сили тромбу, через 30 хв після досягнення МА, у хворих I та II групи не зростав більше 8\% та достовірної різниці між показниками у групах не виявлено. В обох групах хворих на гемофілію А ступінь фібринолізу знаходився в межах норми, що свідчить про відсутність порушень у процесі розчинення згустку у пацієнтів до та після введення у ТВ. Значення тромбодинамічного потенціального індексу (TPI), яке залежить від показників K та MA, у хворих I та II груп знаходилось в межах норми (3,0-20,0)/c). Достовірної різниці показника у групах нами не виявлено ( $\left.\mathrm{p}_{\text {III }}>0,05\right)$. Це свідчить про формування якісного згустку з достатніми гемостатичними можливостями у хворих на гемофілію до та після введення препарату у ТВ.

\section{Висновки:}

1. ТЕГ є надійним методом контролю профілактичного лікування та ТВ у хворих на тяжку форму гемофілії А. Аналізу підлягають показники, значення яких залежить від рівня прокоагулянтів: час реакції $\mathrm{R}$, час досягнення максимальної амплітуди ТМА, кут нахилу до дотичної ТЕГ $\alpha$-Angel, загальний коагуляційний потенціал CI, час від початку тесту до утворення перших ниток фібрину SP.

2. Показники ТЕГ, які характеризують силу, якість, гемостатичні можливості, лізис згустку та залежать від вмісту фібриногену і тромбоцитів, не відрізняються від відповідних показників здорових осіб та є неінформативними для контролю замісної трансфузійної терапії та ТВ у хворих на гемофілію.

3. У хворих на гемофілію моніторинг профілактичного лікування та появи інгібіторів до ФVIII може здійснюватись на основі ТВ за допомогою ТЕГ у комплексі із іншими тестами дослідження гемостазу: АЧТЧ, І АЧТЧ, активність ФVIII та ФVIII: Ag.

\section{References:}

1. Fischer K, Ljung R. Primary prophylaxis in haemophilia care: Guideline update 2016. Blood Cells, Molecules, and Diseases. 2017. March; 67:81-5.

2. Van Den Berg HM. Epidemiological aspects of inhibitor development redefinethe clinical importance of inhibitors. Haemophilia. 2014. May; 20(4):76-9. DOI: 10.1111/hae.12404.

3. Collins PW, Chalmers E, Hart DP, Liesner R, Rangarajan $\mathrm{S}$, Talks $\mathrm{K}$, Williams $\mathrm{M}$, et al. Diagnosis and treatment of factor VIII and IX inhibitors in congenital haemophilia (4th ed). Br.J.Haematol. 2013. Jan; 160(2):15370. DOI: $10.1111 /$ bjh. 12091 .

4. Ramiz S, Hartmann J, Young G, Escobar MA, Chitlur M. Clinical utility of viscoelastic testing (TEG and ROTEM analyzers) in the management of old and new therapies for hemophilia. Am.J.Hematol. 2018. Feb; 94(2):249-56. DOI: 10.1002/ajh.25319.

5. Chitlur M, Rivard GE, Lillicrap D, Mann K, Shima M, Young G. Recommendations for performing thromboelastography/thromboelastometry in hemophilia: communication from the SSC of the ISTH. J. Thromb. Haemost. 2014. Jan; 12(1):103-6. DOI: 10.1111/jth.12458.

6. Furukawa S, Nogami K, Ogiwara K, Yada K, Minami $\mathrm{H}$, Shima M. Systematic monitoring of hemostatic management in hemophilia A patients with inhibitor in the perioperative period using rotational thromboelastometry. J.Thromb.Haemost. 2015. Jul; 13(7):1279-84. DOI: 10.1111/jth.12987.

7. Lancé MD. A general review of major global coagulation assays: thrombelastography, thrombin generation test and clot waveform analysis. Thromb J. 2015. Jan; 13:1. DOI:10.1186/1477-9560-13-1.

8. Verma A, Hemlata. Thromboelastography as a novel viscoelastic method for hemostasis monitoring: Its methodology, applications, and constraints. Glob.J. Transfus.Med. 2017.2 Mar; $2(1): 8-18$. DOI:10.4103/GJTM.GJTM 417

9. Da Luz LT, Nascimento B, Shankarakutty AK, Rizoli S, Adhikari NK. Effect of thromboelastography (TEG®) and rotational thromboelastometry (ROTEM $\AA$ ) on diagnosis of coagulopathy, transfusion guidance and mortality in trauma: descriptive systematic review. Crit. Care. 2014. Sep, 27; 18(5):518. DOI: 10.1186/s13054-014-0518-9.

10. Lamoshi AY, Wilson AM. Thromboelastography parameters versus classical coagulation profile in trauma patients: Retrospective study. Nigerian J. Surgical Research. 2016. Nov; 17(2):33-7. DOI: 10.4103/15951103.194214.

11. Krasivska VV, Stasyshyn OV, Novak VL. Laboratorna diagnostyka vrodzhenyh gemoragichnyh zahvoruvan. Lviv: RVA Triumf; 2014. P.71.

12. Favaloro EJ, Verbruggen B, Miller CH. Laboratory testing for factor inhibitors. Haemophilia. 2014. May; 20(4):94-8. Doi: 10.1111/hae.12408.

\section{УДК 616.151.514-085-071 \\ РОЛЬ ТРОМБОЭЛАСТГРАФИИ В КОНТРОЛЕ ПРОФИЛАКТИЧЕСКОГО ЛЕЧЕНИЯ БОЛЬНЫХ ТЯЖЕЛОЙ ФОРМОЙ ГЕМОФИЛИИ А БЕЗ ИНГИБИТОРОВ}

В.В. Красивская ${ }^{1}$, А.В. Стасишин ${ }^{2}$, М.М. Семерак ${ }^{2}$, O.M. Тушницкий ${ }^{3}$

ГУ «Институт патологии крови и трансфузионной медицины НАМН Украиныл»,

'Лаборатория иммунологии и генетики неоплазий крови,

${ }^{2}$ Отделение общей и гематологической хирургии,

${ }^{3}$ Центр трансплантации стволовых и гемопоэтических клеток, г. Львов, Украина,

ORCID ID: 0000-0002-7048-0711,

ORCID ID: 0000-0002-8366-5926,

ORCID ID: 0000-0001-7394-2590,

ORCID ID: 0000-0003-2106-5623,

e-mail:ipktm@ukr.net 
Резюме. Цель. На основе изучения показателей ТЭГ и традиционных тестов исследования гемостаза усовершенствовать лабораторный мониторинг профилактического лечения препаратами концентратов факторов больных гемофилией А.

Материалы и методы. Исследование выполнено у 9 больных тяжелой формой гемофилии А без ингибиторов, профилактическая доза лечения которых составляла $45 \pm 5 \mathrm{ME} /$ кг фактора свертывания VIII (ФVIII) 2 раза в неделю. Определение проводили на плановом визите в тесте восстановления (ТВ) (доза $60 \pm 5 \mathrm{ME} /$ кг). Анализировали показатели ТЭГ в комплексе с показателями гемостаза, активностью ФVIII, антигеном ФVIII (ФVIII: Ag), антигеном фактора Виллебранда (vWF: Ag).

Результаты. До введения препарата ФVIII тесты, обусловливающие коагуляционный гемостаз, были достоверно удлиненными по сравнению со здоровыми лицами. В ТВ до введения препарата показатели ТЭГ, которые зависят от уровня прокоагулянтов, нарушены в сторону гипокоагуляции. Через 30 мин после введения АЧТВ, И АЧТВ, активность ФVIII и ФVIII: Ag, R, TMA, $\alpha$-Angel, СИ, SP нормализуются.

Выводы. ТЭГ является надежным методом контроля профилактического лечения и ТВ у больных тяжелой формой гемофилии А. Анализу подлежат показатели, значения которых зависят от уровня прокоагулянтов: время реакции $\mathrm{R}$, время достижения максимальной амплитуды ТМА, угол наклона к касательной ТЭГ $\alpha$-Angel, общий коагуляционный потенциал CI, время от начала теста до образования первых нитей фибрина SP. Показатели ТЭГ, характеризующие силу, качество, гемостатические возможности, лизис сгустка и зависят от содержания фибриногена и тромбоцитов, не отличаются от соответствующих показателей здоровых лиц и является неинформативными для контроля заместительной трансфузионной терапии и ТВ у больных гемофилией. У больных гемофилией мониторинг профилактического лечения и появления ингибиторов к ФVIII может осуществляться на основе ТВ с помощью ТЭГ в комплексе с другими тестами исследования гемостаза: АЧТВ, И АЧТВ, активностью ФVIII и ФVIII: Ag.

Ключевые слова: гемофилия, профилактика, тромбоэластография.

\section{UDC 616.151.514-085-071}

\section{THROMBOELASTOGRAPHY SIGNIFICANCE IN THE MONITORING OF PROPHYLACTIC TREATMENT IN PATIENTS WITH SEVERE HAEMOPHILIA A WITHOUT INHIBITORS}

\author{
V.V. Krasivska ${ }^{1}$, O.V. Stasyshyn ${ }^{2}$, M.M. Semerak ${ }^{2}$, \\ O.M. Tushnytskyi ${ }^{3}$
}

State institution "Institute of Blood Pathology and Transfusion Medicine under the NAMS of Ukraine"

${ }^{1}$ Laboratory of immunology and genetics of blood cell neoplasia,

${ }^{2}$ Department of general and heamatological surgery, ${ }^{3}$ Hemopoietic stem cells transplantation center,
Lviv, Ukraine,

ORCID ID: 0000-0002-7048-0711,

ORCID ID: 0000-0002-8366-5926,

ORCID ID: 0000-0001-7394-2590,

ORCID ID: 0000-0003-2106-5623,

e-mail:ipktm@ukr.net

Abstract. Prophylactic treatment of patients with hemophilia A and B is conducted to prevent spontaneous bleeding and the development of hemophilic arthropathy. The high cost of concentrate coagulation factors requires their optimized and rational use. The study of pharmacokinetics (incremental recovery-IR) is the basis for choosing the dose of the concentrate, the frequency of administration and the control of the development of inhibitors. In addition, global laboratory methods, in particular thromboelastography (TEG), are used to control therapy. During monitoring of the prophylaxis with activated partial thromboplastin time (APTT) and FVIII activity, the cause of the discrepancy may be unaccounted content of the tissue factor, the amount and the aggregative function of the thrombocytes, which are also involved in the coagulation process. Therefore, the study of TEG informativity for the assessment of hemostatic effects and the control of treatment with concentrates of factors in hemophilia patients is a relevant problem.

Aim. To study TEG and traditional hemostasis tests to improve laboratory monitoring of concentrate agents' prophylactic treatment for patients with hemophilia A.

Materials and methods. The study was performed in nine patients with severe hemophilia A, who received prophylactic treatment by prolonged recombinant FVIII concentrate at a dose of $45 \pm 5 \mathrm{IU} / \mathrm{kg}$ two times a week. According to international recommendations, all the patients were tested for incremental recovery (IR) of the administered concentrate FVIII in a dose of $60 \pm 5 \mathrm{IU} / \mathrm{kg}$ during their routine visits. Pre- and postinfusion coagulation tests and TEG (TEG 5000® Haemoscope Corp., Niles IL) were performed.

Results. Pre-infusion the indicators of coagulation tests that characterized coagulation hemostasis (APTT-72,9 sec, FVIII-1,1\%) were prolonged. 30 minutes post-infusion the abnormal value came to the norm. The prothrombin time (PT), the fibrinogen level and quantity of platelets in the IR test did not differ from the corresponding values of healthy individuals. In TEG, the prolonged reaction time to clot formation $\mathrm{R}(21,9 \mathrm{sec})$, the time of maximum amplitude TMA $(46,5 \mathrm{sec})$, the time of initial fibrin formation SP (19,1 min), the reduced rate of initial clot strengthening $\alpha$-Angel $\left(33,0^{\circ}\right)$, negative value of coagulation index CI $(-3,0)$ indicate a violation of the enzymatic phase of blood clotting. Post-infusion of the calculated dose of the medication, all of the abnormal parameters returned to normal. In IR test, TEG parameters that characterize strength, quality, hemostatic capabilities, and lysis of the clot and depend on the level of fibrinogen and platelets do not differ from those of healthy individuals.

Conclusion. TEG can be a reliable method for monitoring prophylactic treatment and IR in patients with hemophilia A. The following parameters that depend on the level of procoagulants should be analyzed: the reac- 
tion time to clot formation $\mathrm{R}$, the time of maximum amplitude TMA, initial fibrin formation SP, the rate of initial clot strengthening $\alpha$-Angel, the total coagulation potential CI. TEG parameters that characterize strength, quality, hemostatic capabilities, and lysis of the clot and depend on the level of fibrinogen and platelets are not informative for monitoring prophylactic treatment and IR in patients with hemophilia. Monitoring of prophylaxis and development of inhibitors by IR in patients with hemophilia can be done using TEG in combination with coagulation tests (APTT, IAPTT, FVIII activity, FVIII: Ag).

Keywords: hemophilia, prophylaxis, thromboelastographic.

Стаття надійшла в редакцію 16.02.2019 р. 